\title{
Transformation of Agriculture Through Digitalization, Innovative Solutions, and Information Technologies
}

\author{
O. V. Vaganova \\ Belgorod State University \\ Russian Federation \\ vaganova@bsu.edu.ru \\ Y. L. Aulov \\ Belgorod State University \\ Russian Federation
}

\author{
N. E. Solovjeva \\ Belgorod State University \\ Russian Federation \\ solovjeva@bsu.edu.ru \\ L. I. Prokopova \\ Belgorod State University \\ Russian Federation
}

\begin{abstract}
The article considers the technological mechanisms used in the agricultural sector of developed countries and substantiates the need to implement them in the economy of the Russian Federation. New technologies will allow to reduce the time spent on production (sowing), to retain workforce and to lower the cost of agricultural production by about 5-15\%. The necessity of developing a comprehensive model which will organize the work of all participants in the agricultural market into a single network is proved. The Digital Agriculture program of the Russian Federation is analyzed, as well as its strengths and weaknesses. Main strengths are effective activities of particular regions that are already using drone technologies in agriculture. The article determines the necessity to increase the growth rate of investments in capital assets of agricultural enterprises for the intensive introduction of new technologies in the agribusiness. It was agreed that in the near future the Russian agribusiness has to solve a number of problems including digital transformation, reduction of logistics losses and search for new markets for agricultural products that will contribute to strengthening the economic security of the country in general.
\end{abstract}

Keywords: agribusiness, agro-industrial complex, agriculture, digitalization, innovations, innovative technologies, information technologies, agricultural products

\section{INTRODUCTION}

The most important problem of agribusiness of the Russian Federation is the overall technical and technological lag. In most cases, agricultural production is at the same level as at the previous century. In general, modernization of agribusiness is characterized by lower diffusion of technology, which is determined largely by the condition of capital assets and staff qualifications. World and European experience shows agricultural endeavors should be implemented in an integrated way with the implementation of new technologies, using high-tech equipment and recruiting highly skilled employees. Therefore, Russia is highly focused on these aspects now.

At a new stage of reform, the Government of the Russian Federation raises the question of increasing production efficiency and implementing innovative and information tools for the modernization of the agribusiness, which will increase the level of digitalization.

The leading agricultural producing countries have already experienced a digital transformation and widely use geoinformation technologies, multi-operation energy-saving agricultural units, selection of high-yielding plant varieties and creation of new highly productive animal breeds, biologically active feed additives, new medicines for animals, modern methods of combating epizootics, quarantine diseases of animals and plants. Figure 1 shows the using of drone technology in agriculture in foreign countries: China, the USA, Japan, Brazil, EU countries.

Unconditionally, full or partial automated production of the agricultural sector does not solve all the problems, but it diminishes the time needed for the production (sowing), preserves labor force and reduces the cost of agricultural production by about $5 \approx 15 \%$. Therefore, developing integrated models and organizational and economic mechanism, processes, as well as joint work to unite agricultural market participants into an integrated network of farmers, logistics company for the delivery and sale of agricultural products are required. [RosBiznesConsulting (RBK Group), 2019].

An integrated network can be created using digital (information) technologies [Semilyakova K.V., 2019]. This is related to the fact all necessary indicators including vaccination and optimal breeding work should be considered in all complexes of production and managerial tasks. It eliminated the possibility of errors caused by human factor; 


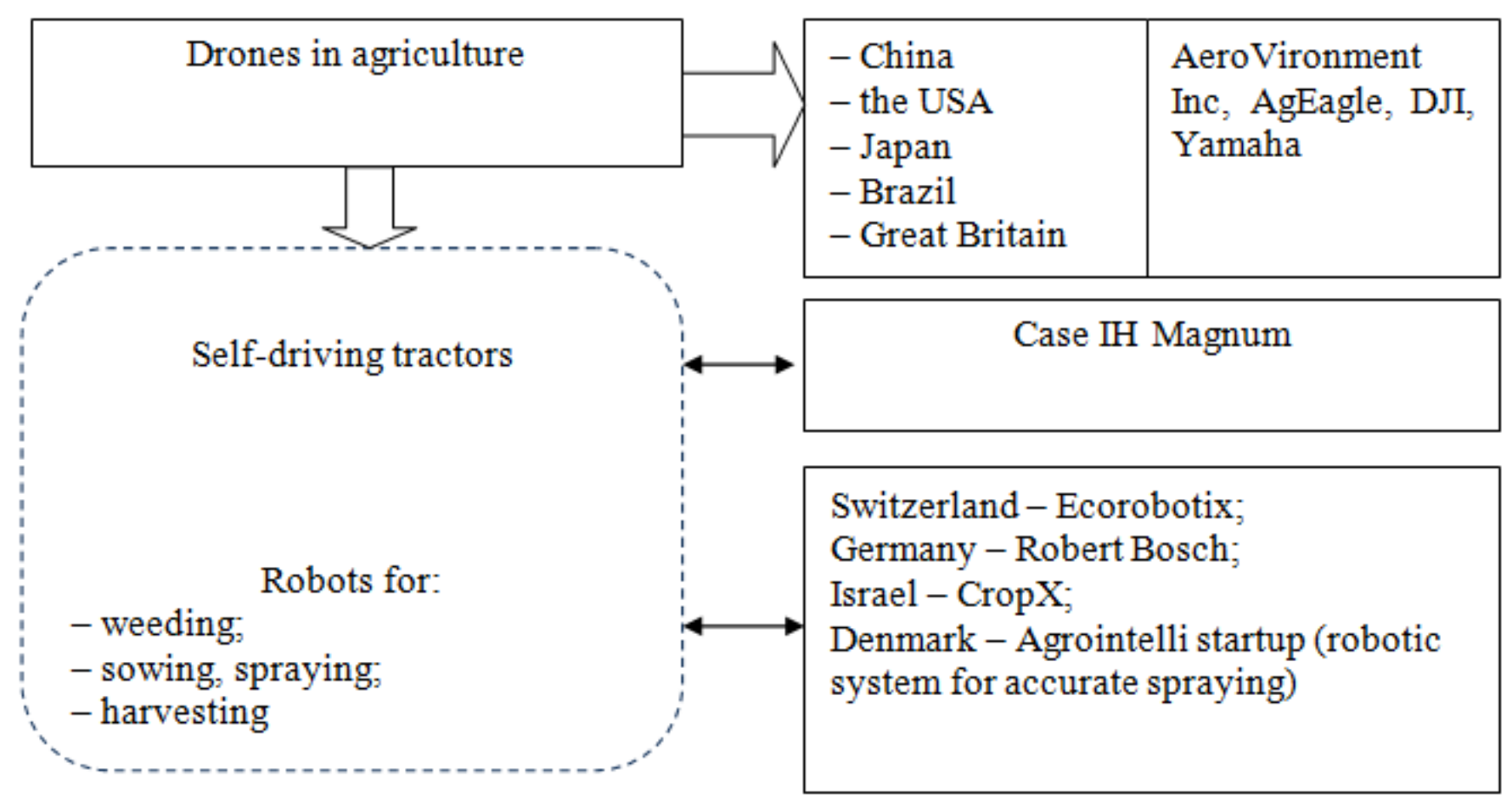

Fig. 1. The digital transformation of the world community of agricultural producers

other heredity. All this allows to significantly increase the profitability of agricultural enterprises and their competitiveness on the global market. [IT in the Russian agribusiness, 2019].

The Government of the Russian Federation pays quite a lot of attention to issues of developing and increasing the efficiency of the agricultural sector. This process is possible to be tracked by adopted laws and regulations and adopted development agenda. Agricultural Development National Project states measures to solve the problems of modernization and equipping of capital assets of farmers. Its objectives have already had examples of solving these problems within the Russian Federation. [Information technology in agriculture, 2019].

Due to the measures taken in the regions, new farming technology has been successfully used (Fig. 2). Thus, 33 own automated information systems have been currently launched in the regions and 7 are now under development. The leaders in this direction are Belgorod, Vladimir, Volgograd, Kostroma regions and Krasnodar Territory [Final progress report of the Ministry of Agriculture of the Russian Federation for, 2018].

Belgorod National State Research University (BelSU) is an integrator of networking between the participants of the Belgorod Regional Research and Education Center (REC) "Innovative Solutions in Agriculture", which is currently in

\begin{tabular}{|l|l|}
\hline \multicolumn{1}{|c|}{ Drones in agriculture } \\
\hline $\begin{array}{l}\text { Robots for: } \\
- \text { sowing, spraying; } \\
- \text { harvesting }\end{array}$
\end{tabular}$\rightarrow \begin{aligned} & \text { In the Russian Federation: } \\
& - \text { AgroBot (Self-driving tractor) } \\
& - \text { Cognitive Agro Pilot (automatic driving } \\
& \text { systems) } \\
& \text { Drone Technologies (Novosibirsk), Geoscan } \\
& \text { (St. Petersburg), Autonomous Aerospace } \\
& \text { Systems - GeoService (Krasnoyarsk) and } \\
& \text { ZALA AERO (Izhevsk). }\end{aligned}$

Fig. 2. The digital transformation of the Russian community of agricultural producers 
TABLE I. THE SHARE OF INVESTMENTS AIMED AT RECONSTRUCTION AND MODERNIZATION IN THE TOTAL VOLUME OF INVESTMENTS IN CAPITAL ASSETS, $\%$

\begin{tabular}{|c|c|c|c|c|c|c|c|c|c|}
\hline & $\mathbf{2 0 1 0}$ & $\mathbf{2 0 1 1}$ & $\mathbf{2 0 1 2}$ & $\mathbf{2 0 1 3}$ & $\mathbf{2 0 1 4}$ & $\mathbf{2 0 1 5}$ & $\mathbf{2 0 1 6}$ & $\mathbf{2 0 1 7}$ & $\mathbf{2 0 1 8}$ \\
\hline Russian Federation $^{\mathrm{a}}$ & 18.8 & 19.3 & 19.5 & 18.8 & 17.4 & 17.3 & 16.3 & 16.1 & 15.5 \\
\hline Central Federal Area & 22.8 & 25.2 & 24.7 & 21.7 & 21.3 & 21.7 & 18.8 & 17.0 & 16.7 \\
\hline Belgorod Region $^{\mathrm{b}}$ & 13.7 & 12.6 & 21.9 & 16.1 & 16.4 & 16.8 & 15.7 & 23.6 & 20.1 \\
\hline
\end{tabular}

a. Rosstat: online collection "Russia in figures" - issue 2018.

b. The Belgorod region in figures. (2019): Short statistical collection / Belgorodstat, 252.

the process of creating. By 2022, an interdisciplinary laboratory or world-class center are planned to operate in each of the main areas of scientific research of the REC, appropriate personnel and infrastructure support provided. With the participation of leading institutes of the Russian Academy of Sciences, the Belgorod National State Research University (BelSU) will create scientific departments of biotechnology, breeding and genetic research, cell technology and genetic engineering (animal and plant genetics), digital transformation of the agricultural sector and resource-saving technologies, technologies for functional, healthy nutrition products, storage and processing of agricultural products [Research and education center "Innovative solutions in agriculture», 2019].

The digitalization of the economy may only be conducted stage by stage from micro to macro levels, from enterprises to industries [Lazeev V., Safonov A., 2019]. Involving all participants of the production process from processing to sales in the digitalization process will go through many obstacles, so it is important to launch pilot projects to implement digital technologies into the industry system at the level of a particular region, and then a certain local territory.

Agribusiness in Russia has reached a certain level of maturity [Strategy of innovative development of the Russian Federation up to 2020]. The introduction and development of drone technologies occurred due to a dynamically growing level of investments aimed at the reconstruction and modernization of agriculture (Table 1).

The Belgorod region came to the third position by the volume of the gross domestic product in the Central Federal District (CFD) following Moscow and the Moscow region, the volume of investment has shown growth by $17 \%$ with the previous period, with dynamics of the foreign trade turnover decreasing by 1.5 times [Vaganova O.V., Titov A. B., Solovjeva N.E., Bykanova N.I., 2017]. The development of agriculture is the main component in the economy of the region, $58 \%$ of the gross municipal product is accounted for by agricultural production [Resolution Of the government of the Belgorod region]. Belgorod region has a significant reserve of increasing the efficiency of agricultural production through the introduction of digital technologies in such industries as crop production, livestock, cattle breeding and others, and, consequently, the emergence of additional jobs, improving the economic climate [Vaganova O.V., Solovjeva N.E. Kulik A.M., Koryakov D.P., 2019].

Digital information technologies in agriculture was previously confined to the use of computers and software primarily for managing financial and accounting statements or tracking business transactions. Currently, farmers have begun to use technology to monitor crops, livestock and various elements of the agricultural process, implement various startups, road maps, etc. Therefore, digital information technologies have evolved and due to this there has been an increase in the efficiency of agricultural enterprises including control of the full cycle of crop production or animal husbandry through smart devices that transmit and process the current parameters of each object and its environment (equipment and sensors measuring the parameters of soil, plants, microclimate, animal characteristics, etc.), as well as seamless communication channels between them and partners.

Due to the unification of objects into an integrated network, the exchange and management of data through the Internet of things (IoT), the increased productivity of computers, the development of software and cloud platforms, it became possible to automate the maximum number of agricultural processes by creating a virtual (digital) model of the entire production cycle and interrelated elements of value chain, and to plan a work schedule with mathematical precision, take emergency measures to prevent losses in the event of fixed threats, calculate possible yield or production costs and profits. Therefore, the improvement of the activities of domestic agricultural enterprises is necessary to ensure the economic development of Russia as a whole, since such enterprises ensure the production of agricultural products, and the consumers of these products are the population [Vaganova O. V., Soloviova N. E., Bikanova N. I., Melnikova N.S., 2017].

\section{CONCLUSION}

Russian agribusiness has several special tasks to accomplish, including digital transformation, pursuit of new niche markets and expanding the logistics and export potential.

The digitalization of the agro-industrial complex stated in the Digital Agriculture program will contribute to increasing the growth of crop and livestock production up to 1.5 times in 2025 [Departmental project "Digital Agriculture", 2019]: will improve the quality of agricultural products, reduce the labor intensity of agricultural production by 1.5 times in 2025, and will reduce production costs and costs of using energy and materials. These factors will affect the level of productivity, neutralize the country's import dependence in high-tech agricultural machinery, and will allow to develop and accelerate digitalization processes through the spread and 
controlengrussia.com/otraslevye-resheniya/sel-skoehozyajstvo/zelenaja-revoljucija/.

promotion of automation, the use of robotics, intelligent machines and domestic technologies.

\section{References}

[1] "What will be the digital future of agriculture in Russia", RosBiznesConsulting (RBK Group), 2019 (In Russian) [Electronic resource]. Available ttps://www.rbc.ru/trends/innovation/5d67bbf49a7947c7eb6a630c.

[2] K.V. Semilyakova, "Application of information technology in the agricultural sector", 2019 (In Russian) [Electronic resource]. Available at: http://nauka-rastudent.ru/12/2246/.

[3] IT in the Russian agribusiness, 2019 (In Russian) [Electronic resource]. Available at: http://dialog-e.ru/market-news/408/.

[4] "Information technology in agriculture", Official site of the Federal center of agricultural consulting services and retraining staff of agricultural complex 2019 (In Russian) [Electronic resource]. Available at: http://mcx-consult.ru/page0310082009.

[5] Final progress report of the Ministry of Agriculture of the Russian Federation for 2018 (In Russian) [Electronic resource]. Available at: http://mcx.ru/upload/iblock/10c/10c6695082afd0ac0ea4b6e41fa3f6d9.p df (Accessed: 15.04.2019).

[6] Research and education center "Innovative solutions in agriculture", 2019 (In Russian) [Electronic resource]. Available at: https://www.bsu.edu.ru/bsu/info/noc-apk/.

[7] V. Lazeev, A. Safonov, "Prospects for the automation of agricultural enterprises in the agricultural sector", Control Engineering Russia, June 2018, 2019 (In Russian) [Electronic resource]. Available at: http
[8] "Strategy of innovative development of the Russian Federation up to 2020", Approved by the decree of the Government of the Russian Federation of 8 December, no. 2227-r (in Russian). (Accessed: 15.04.2019).

[9] "Rosstat", online collection "Russia in figures", 2018 (in Russian) [Electronic resource]. Available at: https://nangs.org/analytics/rosstatonlajn-sbornik-rossiya-v-tsifrakh-vypusk-2018-goda-pdf.

[10] The Belgorod region in figures. Short statistical collection, Belgorodstat, 252, 2019.

[11] O.V. Vaganova, A.B. Titov, N.E. Solovjeva, and N.I. Bykanova, "Influence of the sanctions regime on the regional innovation system formation (the case of the Belgorod region)", International Journal of Economic Perspectives, vol. 11, iss. 3, September 2017.

[12] "Development of agriculture and fish farming in the Belgorod region", On approval of the state program of the Belgorod Region, Resolution of the government of the Belgorod Region dated 28 October 2013, no. 439-PP, Amended on 8 July 2019 [Electronic resource]. Available at: http://docs.cntd.ru/document/412303790.

[13] O.V. Vaganova, N.E. Solovjeva, A.M. Kulik, and D.P. Koryakov, "Trends in the development of the agroindustrial complex of the Belgorod region in the digital space", The Economics of sustainable development, 4 (40), 2019.

[14] O.V. Vaganova, N.E. Soloviova, N.I. Bikanova, N.S. Melnikova, "Management of outsourcing risks in the process of enterprise", Financial activity, Financial and credit activity: problems of theory and practice, vol. 2, no. 23, pp. 110-117, 2017.

[15] Departmental project "Digital Agriculture": official publication. M.: FSINI "Rosinformagroteh", 48 p., 2019. 